DOI: $10.31393 /$ reports-vnmedical-2019-23(4)-31

UDC: $616.53-008.811 .1: 159.923 .2$

\title{
CONSTITUTIONAL AND PSYCHOLOGICAL FEATURES OF SEBORRHEIC DERMATITIS (ANALYSIS OF SCIENTIFIC LITERATURE)
}

\section{Khasawneh Ahmad Raed}

National Pirogov Memorial Medical University, Vinnytsya (Pyrogov street 56, Vinnytsya, Ukraine, 21018)

Received: September 13, 2019; Accepted: October 18, 2019

Responsible for correspondence: e-mail:dr_ahmad_khasawneh@yahoo.com

Annotation. The purpose of the work is to analyze the scientific literature regarding the constitutional and psychological features of the occurrence and course of seborrheic dermatitis (SD). A review of the literature indicates that diabetes is a multifactorial disease with complex and multifaceted pathogenesis. The works of recent years reflect the involvement in the pathogenesis of SD of virtually all integrating systems of the organism and the main links of its basic functional systems. In the phenotypic manifestation of SD involved both exogenous (physico-chemical, biological) and endogenous (nervous system, genetic predisposition and immune disorders) factors. The pathogenetic mechanisms of dermatitis are polymorphic and do not contradict but complement each other. Studying the constitutional and psychological features of SD in Ukrainian residents is thus a promising area of research.

Keywords: seborrheic dermatitis, course, genetic markers, psychological features, clinical anthropology.

Seborrheic dermatitis (SD) is a common, recurrent disease with chronic progression that affects seborrheic areas, such as skin in the chest, forearms, face, nasal area and scalp. In fact, SD is a marker of disability from the digestive, endocrine, immune, and nervous systems $[3,8$, 13].

The purpose of the work is to analyze the scientific literature regarding the constitutional and psychological features of the occurrence and course of SD.

$\mathrm{SD}$ is common in both women and men and affects more than $1 \%$ to $3 \%$ of adults. It occurs more frequently in infants through the transmission of androgens from mother to child in the first 3 months of life. SD is also common in adolescents and adults, with an increase in frequency among individuals after reaching the age of 50 [19, 29].

Currently, there is no single point of view on the etiopathogenesis of SD. There are a number of neurogenic, psychological, hormonal, immune, infectious, metabolic, genetic factors contributing to the manifestation of this dermatosis, which cause excessive production and qualitative change in sebum, caused by the functional activity of the sebaceous glands and activation of fungi of the genus Malassezia. Psychogenic factors act as a link in the chain of sequential immunological processes, which explains the occurrence or exacerbation of dermatosis only in close connection with the main factors of pathogenesis $[6,18,27]$.

The process of sebum formation in the body is regulated by two main mechanisms: neurogenic and hormonal. Neurogenic regulation is carried out by the autonomic nervous system. This circumstance, for example, explains the increased excretion of sebum and sweating in various vegetative disorders, and clinical manifestations of SD often appear after suffering stress [19].

The central nervous system and the skin are linked through embryological origin; thus, some hormones, neurotransmitters and receptors are common to both. The implementation of the genetic program, leading to the manifestation of the seborrheic process, is carried out with the participation of the neuroendocrine system. It is the neuroendocrine system that is the first to respond to external influences, that is, it is a kind of mediator between the external environment and the skin [14, 30].

Psychological factors play a central role in the onset, exacerbation, and remission of SD. However, there is little scientific evidence to support this view. In addition, there is very limited evidence of personality profiles that lead to emotional dysregulation, such as alexithymia and concomitant psychiatric disorders in these patients [15].

A study by A. Comert and colleagues [10] found that anxiety levels were significantly higher in patients with SD compared to healthy controls, but there was no pronounced association with alexithymia, depression, or compulsivecompulsive symptoms. Dermatologists should be especially vigilant about the possibility of concurrent psychiatric morbidity in patients with SD in order to improve patients' well-being. In some patients, the wrong circle arises: dermatosis is caused or exacerbated by stress, and exacerbation, in turn, is a major stressogenic stimulus.

A. I. Gul et al. [14] reported an association between SD and general psychiatric disorders, as well as major personality traits in patients with SD. Significantly higher rates of depression and anxiety were detected in patients with SD compared to the control group. In addition, significantly more somatization and neurotic personality traits were found in these patients. These data suggest that patients with SD are likely to somatize their emotions. This reflects the likely relationship between SD, personality traits and psychological distress.

Thus, Y. Bas et al. [8] determined that this dermatosis is more common in young people than in adulthood, and the choleric type of temperament associated with it.

L. Manolache et al. [16] have also been closely linked to stress. However, it has been proven that stress in itself is 
less important than the type of patient's perception of a stressful situation.

Increased discharge of sebum is observed in patients with Parkinson's disease, cranial nerve paralysis. Destabilization of the autonomic and hormonal systems in patients may be associated with hereditary disintegration of the antinociceptive system of the hypothalamus, which controls the level of opiate neuropeptides of the blood, and through the pituitary gland - with the functional state of the organs of the endocrine system [4].

Clinically significant of skin differences between ethnic groups have been reported, especially not only with skin color (people with white skin are prone to the disease), but with the formation and sebum excretion processes [21, $26,28]$. The genetic nature of the disease is justified by the possibility of irregular dominance of SD and the most frequent manifestation in patients with III (B) blood group $[17,20]$.

It is suggested that hereditary predisposition is one of the main factors in the development of seborrheic dermatitis. It is characterized by the so-called "seborrheic constitution", which reflects a high genetic predisposition to the development of this disease. Usually, such patients have a family history $[5,8,9]$.

Conducted by I. V. Polesko [7] analysis of class I HLA antigens and specificity of class II DRB1, DQA1, DQB1 in patients with this skin disease substantiated the existence of genetic determinism of the disease and classified as probable markers class $\mathrm{A} 10$ and $\mathrm{A} 23$ antigens I. The skin microbiota changes and its bactericidal properties are reduced, creating a favorable environment for the pathogenic flora, which provokes inflammation [6, 23].

In the development of SD, hormonal imbalance also plays an important role. The hormonal regulation of sebum production involves the adrenal cortex, hypothalamus, pituitary gland, sex glands, which hormones affect the receptors located on sebocytes. The secretion of sebum is directly controlled by androgens, since affinity receptors are located on the surface of sebocytes and epidermocytes $[15,24]$.

The level of total testosterone in the blood of most patients with $S D$ is within the normal range, but the conversion of testosterone is $20-30$ times higher than in healthy subjects. In the affected areas of the skin, this process takes place most intensively [15].

There is evidence of a higher incidence of SD in obese

\section{References}

1. Belousova, T. A., Horiachkyna, M. A., \& Shranova, D. H. (2013). Seborejny`j dermatit volosistoj chasti golovy`: sovremenny`e predstavleniya ob e'tiologii, patogeneze i terapii [Seborrheic dermatitis of the scalp: current understanding of etiology, pathogenesis and therapy]. Vestnik dermatologii i venerologii - Bulletin of Dermatology and Venereology, 6, 132-138.

2. Haidash, A. A., Chyhodaikyn, H. P., Karachëva, Yu. V. Prokhorenkov, V. Y., Nykolaev, V. H., Syndeeva, L. V., \& Babenko, O. N. (2011). Struktura mezhkletochnogo matriksa kozhi razlichny 'kh somatotipov cheloveka po danny'm atomno- individuals, but the exact mechanism of development is unknown. Decreased estrogen levels are a contributing factor in the development of menopausal women [19].

A. A. Gaidash et al. [2] studied the structure and physical properties of the extracellular matrix of the dermis in individuals with different body types using atomic force microscopy. Scientists have concluded that the features of the intercellular substance of the skin depend on the type of constitution and are caused by variations in the viscosity of the interstitial fluid and the structure of the pores. In asthenic, the risks of the inflammatory process in the skin are mainly due to the high rates, but the more specific nature of the generalization. Hypersthenic, on the contrary, have low speeds and generalization of pathological processes in conditions of greater uncertainty.

In patients with SD increased expression of Toll-like receptors, their activation under the influence of various pathogens on macrophages and other cells of innate immunity causes the expression of many genes of chemokines and proinflammatory cytokines [11, 12, 19].

The mechanism of a person's individual predisposition to seborrhea remains virtually unexplored. These are probably congenital disorders of skin permeability, barrier function of the stratum corneum and immune response to free fatty acids or proteins and polysaccharides [1, 13, 22, 25].

Thus, the polymorphism of histological and clinical forms of SD substantiates its multifactorial nature, which combines both genetic predisposition and metabolic disorders and adequate control of the cell cycle.

\section{Conclusions and prospects for further development}

1. From the review of the literature, it became known that information on the etiopathogenesis of seborrheic dermatitis was accumulated a lot, but the transition to quality has not yet occurred, because there was no qualitative breakthrough in the use of personalized algorithms for diagnosis and management of patients combining medical treatment considering the constitutional and psychological characteristics of the patient.

Thus, if we consider SD in terms of multifactoriality, and this is necessary to maximize the effectiveness of therapeutic interventions, it is necessary to recognize that the existing approaches to the search for constitutional and psychological features in each individual need careful study and refinement.

silovoj mikroskopii [The structure of the intercellular matrix of the skin of various human somatotypes according to atomic force microscopy]. Sibirskij mediczinskij zhurnal (Irkutsk) Siberian Medical Journal (Irkutsk), 104(5), 14-17.

3. Yhnatev, D. V., \& Lomonosov, K. M. (2009). E'ffektivnoe lechenie seborejnogo dermatita volosistoj chasti golovy ' [Effective treatment of seborrheic dermatitis of the scalp]. Dermatologiya. Prilozhenie k zhurnalu Consilium Medicum - Dermatology. Magazine supplement Consilium Medicum, 2, 8-10. 
4. Levyna, Yu. V., \& Raznatovskyi, K. Y. (2010). Vegetativnogormonal'ny'e narusheniya pri seborejnom dermatite i ikh korrekcziya metodom transkranial'noj e'lektrostimulyaczil stvola mozga [Vegetative-hormonal disorders in seborrheic dermatitis and their correction by transcranial electrical stimulation of the brain stem]. Rossijskij zhurnal kozhny 'kh i venericheskikh boleznej - Russian Journal of Skin and Sexually Transmitted Diseases, 2, 30-32.

5. Mordovtsev, V. N., Alyeva, P. M., \& Serheev, A. S. (2002). Zabolevaniya kozhi s nasledstvenny'm predraspolozheniem [Diseases of the skin with a hereditary predisposition]. M.: DNCz RAN.

6. Olysova, O. Yu. (2016). Patogenez i lechenie seborejnogo dermatita [Pathogenesis and treatment of seborrheic dermatitis]. E'ffektivnaya farmakoterapiya - Effective pharmacotherapy, 1-2(13), 36-40.

7. Polesko, I. V. (2007). Osobennosti raspredeleniya antigenov II II klassov sistemy' HLA u bol 'ny 'kh seborejny'm dermatitom [Features of the distribution of antigens of classes I and II of the HLA system in patients with seborrheic dermatitis]. Detskie infekczii - Childhood infections, 6(3), 30-34.

8. Bas, Y., Seckin, H. Y., Kalkan, G., Takci, Z., Citil, R., Onder, Y., ... Demir, A. K. (2016). Prevalence and related factors of psoriasis and seborrheic dermatitis: a community-based study. Turkish journal of medical sciences, 46(2), 303-309. doi: 10.3906/ sag-1406-51.

9. Borda, L. J., \& Wikramanayake, T. C. (2015). Seborrheic dermatitis and dandruff: a comprehensive review. Journal of clinical and investigative dermatology, 3(2). doi: 10.13188/ 2373-1044.1000019.

10. Comert, A., Akbas, B., Kiliç, E. Z., Akin, Ö., Gökçe, E., Göktuna, Z., \& Taskapan, O. (2013). Psychiatric comorbidities and alexithymia in patients with seborrheic dermatitis: a questionnaire study in Turkey. American journal of clinical dermatology, 14(4), 335-342. doi: 10.1007/s40257-013-0019-7.

11. Dawson Jr, T. L. (2007). Malassezia globosa and restricta: breakthrough understanding of the etiology and treatment of dandruff and seborrheic dermatitis through whole-genome analysis. Journal of Investigative Dermatology Symposium Proceedings, 12(2), 15-19. doi: 10.1038/sj.jidsymp.5650049.

12. Del Rosso, J. Q., \& Kim, G. K. (2009). Seborrheic dermatitis and Malassezia species: how are they related. J. Clin. Aesthet. Dermatol., 2(11), 14-17. PMID: 20725575.

13. Emre, S., Metin, A., Demirseren, D. D., Akoglu, G., Oztekin, A., Neselioglu, S., \& Erel, O. (2012). The association of oxidative stress and disease activity in seborrheic dermatitis. Archives of dermatological research, 304(9), 683-687. doi: 10.1007/ s00403-012-1254-0.

14. Gül, A. I., Karaaslan, Ö., \& Çölgeçen, E. (2017). Personality traits and common psychiatric conditions in patients with seborrheic dermatitis. Archives of Clinical Psychiatry (Sao Paulo), 44(1), 6-9. doi: 10.1590/0101-60830000000106.

15. Makrantonaki, E., \& Zouboulis, C. C. (2007). Testosterone metabolism to $5 \alpha$-dihydrotestosterone and synthesis of sebaceous lipids is regulated by the peroxisome proliferatoractivated receptor ligand linoleic acid in human sebocytes. British Journal of Dermatology, 156(3), 428-432. doi: 10.1111/ j.1365-2133.2006.07671.x.

16. Manolache, L., \& Petrescu-Seceleanu, D. (2013). Stress involvement as trigger factor in different skin conditions. World J. Dermatol., 2(3), 16-26. doi: 10.5314/wjd.v2.i3.16.

17. Orion, E., \& Wolf, R. (2014). Psychologic factors in the development of facial dermatoses. Clinics in dermatology, 32(6), 763-766. doi: 10.1016/j.clindermatol.2014.02.015.

18. Palamaras, I., Kyriakis, K. P., \& Stavrianeas, N. G. (2012). Seborrheic dermatitis: lifetime detection rates. Journal of the European Academy of Dermatology and Venereology, 26(4),
524-526, doi: 10.1111/j. 1468-3083.2011.04079.x

19. Plewig, G., \& Jansen, T. (Ed. Wolf, K., Goldsmith, L., Katz, S. I.) (2008). Seborrheic dermatitis. Fitzpatrick's Dermatology in General Medicine. McGraw-Hill Companies.

20. Rather, P. A., Hassan, I., Naaz, S., Rasool, F., \& Reshi, R. (2016). Evaluation of $A B O$ blood types in various dermatoses in Kashmiri population: A case-control study. Journal of Pakistan Association of Dermatology, 24(3), 224-230.

21. Rawlings, A. V. (2006). Ethnic skin types: are there differences in skin structure and function? International Journal of Cosmetic Science, 28(2), 79-93. doi: https://doi.org/10.1111/ j.1467-2494.2006.00302.x

22. Schwartz, J. R., Messenger, A. G., Tosti, A., Todd, G., Hordinsky, M., Hay, R. J., ... \& Rust, R. C. (2013). A comprehensive pathophysiology of dandruff and seborrheic dermatitistowards a more precise definition of scalp health. Acta dermato-venereologica, 93(2), 131-137. doi: 10.2340/ 00015555-1382.

23. Tanaka, A., Cho, O., Saito, C., Saito, M., Tsuboi, R., \& Sugita, T. (2016). Comprehensive pyrosequencing analysis of the bacterial microbiota of the skin of patients with seborrheic dermatitis. Microbiology and immunology, 60(8), 521-526. doi: 10.1111/1348-0421.12398.

24. Viode, C., Lejeune, O., Turlier, V., Rouquier, A., Casas, C., Mengeaud, V., ... \& Schmitt, A. M. (2014). Cathepsin S, a new pruritus biomarker in clinical dandruff/seborrhoeic dermatitis evaluation. Experimental dermatology, 23(4), 274-275. doi: 10.1111/exd.12357.

25. Vlachos, C., Gaitanis, G., Alexopoulos, E. C., Papadopoulou, C., \& Bassukas, I. D. (2013). Phospholipase activity after $\beta$ endorphin exposure discriminates Malassezia strains isolated from healthy and seborrhoeic dermatitis skin. Journal of the European Academy of Dermatology and Venereology, 27(12), 1575-1578. doi: 10.1111/j.1468-3083.2012.04638.x.

26. Wan, D. C., Wong, V. W., Longaker, M. T., Yang, G. P., \& Wei, F. C. (2014). Moisturizing different racial skin types. The Journal of clinical and aesthetic dermatology, 7(6), 25-32. doi: PMID: 25013536.

27. Weidmann, A. K., \& Al-Niaimi, F. (2012). Seborrhoeic dermatitis in adults and infants. Dermatological Nursing, 11(3), 36-39.

28. Yamashita, Y., Okano, Y., Ngo, T., Buche, P., Sirvent, A., Girard, F., \& Masaki, H. (2012). Differences in susceptibility to oxidative stress in the skin of Japanese and French subjects and physiological characteristics of their skin. Skin pharmacology and physiology, 25(2), 78-85. doi: 10.1159/000335259.

29. Zander, N., Sommer, R., Schafer, I., Reinert, R., Kirsten, N., Zyriax, B. C., ... \& Augustin, M. (2019). Epidemiology and dermatological comorbidity of seborrhoeic dermatitis: population based study in 161269 employees. British Journal of Dermatology, 181(4), 743-748. doi: 10.1111/bjd.17826.

30. Zouboulis, C. C., Baron, J. M., Bohm, M., Kippenberger, S., Kurzen, H., Reichrath, J., \& Thielitz, A. (2008). Frontiers in sebaceous gland biology and pathology. Experimental dermatology, 17(6), 542-551. doi: 10.1111/j.16000625.2008.00725.x.

\section{Список посилань}

1. Белоусова, Т. А., Горячкина, М. А., \& Шранова, Д. Г. (2013). Себорейный дерматит волосистой части головы: современные представления об этиологии, патогенезе и терапии. Вестник дерматологии и венерологии, 6, 132-138.

2. Гайдаш, А. А., Чигодайкин, Г. П., Карачёва, Ю. В., Прохоренков, В. И., Николаев, В. Г., Синдеева, Л. В., \& Бабенко, О. Н. (2011). Структура межклеточного матрикса кожи различных соматотипов человека по данным атомно-силовой микроскопии. Сибирский медицинский журнал (Иркутск), 104(5), 14-17. 
3. Игнатьев, Д. В., \& Ломоносов, К. М. (2009). Эфффективное лечение себорейного дерматита волосистой части головы. Дерматология. Приложение к журналу Consilium Medicum, 2, 8-10.

4. Левина, Ю. В., \& Разнатовский, К. И. (2010). Вегетативногормональные нарушения при себорейном дерматите и их коррекция методом транскраниальной электростимуляции ствола мозга. Российский журнал кожных и венерических болезней, 2, 30-32.

5. Мордовцев, В. Н., Алиева, П. М., \& Сергеев, А. С. (2002) Заболевания кожи с наследственным предрасположением. М.: ДНЦРАН.

6. Олисова, О. Ю. (2016). Патогенез и лечение себорейного дерматита. Эфффективная фрармакотерапия, 1-2(13), 3640.

7. Полеско, И. В. (2007). Особенности распределения антигенов I И II классов системы HLA у больных себорейным дерматитом. Детские инфекции, 6(3), 30-34.

8. Bas, Y., Seckin, H. Y., Kalkan, G., Takci, Z., Citil, R., Onder, Y., ... Demir, A. K. (2016). Prevalence and related factors of psoriasis and seborrheic dermatitis: a community-based study. Turkish journal of medical sciences, 46(2), 303-309. doi: 10.3906/ sag-1406-51.

9. Borda, L. J., \& Wikramanayake, T. C. (2015). Seborrheic dermatitis and dandruff: a comprehensive review. Journal of clinical and investigative dermatology, 3(2). doi: 10.13188/ 2373-1044.1000019.

10. Comert, A., Akbas, B., Kiliç, E. Z., Akin, Ö., Gökçe, E., Göktuna, Z., \& Taskapan, O. (2013). Psychiatric comorbidities and alexithymia in patients with seborrheic dermatitis: a questionnaire study in Turkey. American journal of clinical dermatology, 14(4), 335-342. doi: 10.1007/s40257-013-0019 7.

11. Dawson Jr, T. L. (2007). Malassezia globosa and restricta: breakthrough understanding of the etiology and treatment of dandruff and seborrheic dermatitis through whole-genome analysis. Journal of Investigative Dermatology Symposium Proceedings, 12(2), 15-19. doi: 10.1038/sj.jidsymp.5650049.

12. Del Rosso, J. Q., \& Kim, G. K. (2009). Seborrheic dermatitis and Malassezia species: how are they related. J. Clin. Aesthet. Dermatol., 2(11), 14-17. PMID: 20725575.

13. Emre, S., Metin, A., Demirseren, D. D., Akoglu, G., Oztekin, A., Neselioglu, S., \& Erel, O. (2012). The association of oxidative stress and disease activity in seborrheic dermatitis. Archives of dermatological research, 304(9), 683-687. doi: 10.1007/ s00403-012-1254-0.

14. Gül, A. I., Karaaslan, Ö., \& Çölgeçen, E. (2017). Personality traits and common psychiatric conditions in patients with seborrheic dermatitis. Archives of Clinical Psychiatry (Sao Paulo), 44(1), 6-9. doi: 10.1590/0101-60830000000106.

15. Makrantonaki, E., \& Zouboulis, C. C. (2007). Testosterone metabolism to $5 \alpha$-dihydrotestosterone and synthesis of sebaceous lipids is regulated by the peroxisome proliferatoractivated receptor ligand linoleic acid in human sebocytes. British Journal of Dermatology, 156(3), 428-432. doi: 10.1111/ j.1365-2133.2006.07671.x

16. Manolache, L., \& Petrescu-Seceleanu, D. (2013). Stress involvement as trigger factor in different skin conditions. World J. Dermatol., 2(3), 16-26. doi: 10.5314/wjd.v2.i3.16.

17. Orion, E., \& Wolf, R. (2014). Psychologic factors in the development of facial dermatoses. Clinics in dermatology, 32(6), 763-766. doi: 10.1016/j.clindermatol.2014.02.015.

18. Palamaras, I., Kyriakis, K. P., \& Stavrianeas, N. G. (2012) Seborrheic dermatitis: lifetime detection rates. Journal of the European Academy of Dermatology and Venereology, 26(4), 524-526. doi: 10.1111/j.1468-3083.2011.04079.x

19. Plewig, G., \& Jansen, T. (Ed. Wolf, K., Goldsmith, L., Katz, S. I.) (2008). Seborrheic dermatitis. Fitzpatrick's Dermatology in General Medicine. McGraw-Hill Companies.

20. Rather, P. A., Hassan, I., Naaz, S., Rasool, F., \& Reshi, R. (2016). Evaluation of ABO blood types in various dermatoses in Kashmiri population: A case-control study. Journal of Pakistan Association of Dermatology, 24(3), 224-230.

21. Rawlings, A. V. (2006). Ethnic skin types: are there differences in skin structure and function? International Journal of Cosmetic Science, 28(2), 79-93. doi: https://doi.org/10.1111/ j.1467-2494.2006.00302.x

22. Schwartz, J. R., Messenger, A. G., Tosti, A., Todd, G., Hordinsky, M., Hay, R. J., ... \& Rust, R. C. (2013). A comprehensive pathophysiology of dandruff and seborrheic dermatitistowards a more precise definition of scalp health. Acta dermato-venereologica, 93(2), 131-137. doi: 10.2340/ 00015555-1382.

23. Tanaka, A., Cho, O., Saito, C., Saito, M., Tsuboi, R., \& Sugita, T. (2016). Comprehensive pyrosequencing analysis of the bacterial microbiota of the skin of patients with seborrheic dermatitis. Microbiology and immunology, 60(8), 521-526. doi: 10.1111/1348-0421.12398.

24. Viode, C., Lejeune, O., Turlier, V., Rouquier, A., Casas, C., Mengeaud, V., ... \& Schmitt, A. M. (2014). Cathepsin S, a new pruritus biomarker in clinical dandruff/seborrhoeic dermatitis evaluation. Experimental dermatology, 23(4), 274-275. doi: 10.1111/exd.12357

25. Vlachos, C., Gaitanis, G., Alexopoulos, E. C., Papadopoulou, C., \& Bassukas, I. D. (2013). Phospholipase activity after $\beta$ endorphin exposure discriminates Malassezia strains isolated from healthy and seborrhoeic dermatitis skin. Journal of the European Academy of Dermatology and Venereology, 27(12), 1575-1578. doi: 10.1111/j.1468-3083.2012.04638.x.

26. Wan, D. C., Wong, V. W., Longaker, M. T., Yang, G. P., \& Wei, F. C. (2014). Moisturizing different racial skin types. The Journal of clinical and aesthetic dermatology, 7(6), 25-32. doi: PMID: 25013536.

27. Weidmann, A. K., \& Al-Niaimi, F. (2012). Seborrhoeic dermatitis in adults and infants. Dermatological Nursing, 11(3), 36-39.

28. Yamashita, Y., Okano, Y., Ngo, T., Buche, P., Sirvent, A., Girard, F., \& Masaki, H. (2012). Differences in susceptibility to oxidative stress in the skin of Japanese and French subjects and physiological characteristics of their skin. Skin pharmacology and physiology, 25(2), 78-85. doi: 10.1159/000335259.

29. Zander, N., Sommer, R., Schafer, I., Reinert, R., Kirsten, N., Zyriax, B. C., ... \& Augustin, M. (2019). Epidemiology and dermatological comorbidity of seborrhoeic dermatitis: population based study in 161269 employees. British Journal of Dermatology, 181(4), 743-748. doi: 10.1111/bjd.17826.

30. Zouboulis, C. C., Baron, J. M., Bohm, M., Kippenberger, S., Kurzen, H., Reichrath, J., \& Thielitz, A. (2008). Frontiers in sebaceous gland biology and pathology. Experimental dermatology, 17(6), 542-551. doi: 10.1111/j.16000625.2008.00725.x.

\section{КОНСТИТУЦІОНАЛЬНІ ТА ПСИХОЛОГІЧНІ ОСОБЛИВОСТІ СЕБОРЕЙНОГО ДЕРМАТИТУ (АНАЛІЗ НАУКОВОЇ ЛІТЕРАТУРИ)} Хасавнех Ахмад Раед

Анотація. Мета роботи - проаналізувати наукову літературу стосовно конституціональних та психологічних особливостей виникнення та перебігу себорейного дерматиту (СД). Проведений огляд літературних джерел вказує на те, що СД належить до мультифакторіальних захворювань із складним та багатогранним патогенезом. Роботи останніх років віддзеркалюють участь в патогенезі СД практично всіх інтегруючих систем організму та головних ланок його базових 
функціональних систем. У фенотиповому прояві СД залучені як екзогенні (фрізико-хімічні, біологічні), так і ендогенні (нервова система, генетична схильність та імунні порушення) фрактори. Патогенетичні механізми дерматиту поліморфні та не суперечать, а доповнюють один одного. Вивчення конституціональних та психологічних особливостей СД у мешканців України таким чином є перспективним напрямком дослідження.

Ключові слова: себорейний дерматит, перебіг, генетичні маркери, психологічні особливості, клінічна антропологія.

\section{КОНСТИТУЦИОНАЛЬНЫЕ И ПСИХОЛОГИЧЕСКИЕ ОСОБЕННОСТИ СЕБОРЕЙНОГО ДЕРМАТИТА (АНАЛИЗ НАУЧНОЙ ЛИТЕРАТУРЫ) \\ Хасавнех Ахмад Раед}

Аннотация. Цель работы - проанализировать научную литературу о конституциональных и психологических особенностях возникновения и течения себорейного дерматита (СД). Проведенный обзор литературных источников указывает на то, что СД относится к мультифакториальным заболеваниям со сложным и многогранным патогенезом. Работы последних лет отражают участие в патогенезе СД практически всех интегрирующих систем организма и главных звеньев его базовых функциональных систем. К фенотипическим проявлениям СД привлечены как экзогенные (физико-химические, биологические), так и эндогенные (нервная система, генетическая склонность и иммунные нарушения) фракторы. Патогенетические механизмы дерматита полиморфны и не противоречат, а дополняют друг друга. Изучение конституциональных и психологических особенностей СД у жителей Украины таким образом является перспективным направлением исследования.

Ключевые слова: себорейный дерматит, течение, генетические маркеры, психологические особенности, клиническая антропология. 